\title{
KNOWLEDGE SHARING IN AN ORGANIZATION FROM THE PERSPECTIVE OF THE INDIVIDUAL
}

\author{
Dr. Dana Mesner Andolšek, Faculty of Social Sciences, University of Ljubljana, Slovenia \\ E-mail: Dana.Mesner-Andolsek@fdv.uni-lj.si \\ Stanislav Andolšek, Gimnazija Poljane, Ljubljana, Slovenia \\ E-mail: stan.andolsek@siol.net
}

Received: July, 25.2015.

Revised: August, 08.2015.

Accepted: August, 25.2015.

Studies and articles

UDK 005.94

\begin{abstract}
Authors introduce a theoretical model of knowledge sharing in an organization through individual perspective. The social exchange theory offers a clarification of fundamental assumptions regarding individual action and is therefore appropriate for explaining why and when an individual is ready to share her/his knowledge in an organization. The article aims to reveal what shapes employees' decisions to share knowledge in a work situation and what is needed in an organization to facilitate individuals to share and not to hoard their knowledge. These assumptions have never been included in the literature of knowledge management up until now.

Keywords: knowledge sharing in an organization, knowledge management, individual perspective, social exchange theory.
\end{abstract}

\section{INTRODUCTION}

Knowledge sharing in organizations is considered by many researchers, analysts and practitioners as one of the most critical elements of the process of knowledge management (Nonaka and Takeuchi, 1995). Most of them also agree that our understanding of how individuals share knowledge within an organization is poor. The roles of the factors that mediate in this process are also not clear. From the initial orientation in the research, where the emphasis was mainly on the role of technology in knowledge sharing, the attention slowly turned to social relationships in which knowledge is transmitted. In the last decade, the interest in the detection of obstacles and in the promotion of the flow of knowledge within an organization has grown. Despite all the literature the research is to a certain ex-

Corresponding Author

Dr. Dana Mesner Andolšek

Faculty of Social Sciences

University of Ljubljana, Slovenia

E-mail: Dana.Mesner-Andolsek@fdv.uni-lj.si tent unilateral. Obstacles and incentives are frequently discussed solely on the behavioural - empirical level without the authors questioning the assumptions of that model and determine the behaviour of individuals. From this perspective, we believe that such research, which has no theoretical basis, is too weak. In this article we want to transcend the limited scope of existing empirical research and give our perspective on knowledge sharing within an organization. The theory of social exchange is the basis of our research and carries the potential for clarifying the assumptions on how individuals behave in certain situations and what are the latter determined by.

In the following article we will firstly reveal the findings of researchers who discovered how the processes of knowledge sharing unravel in organizations. We will then continue to identify the most common barriers that occur in these processes. Our basic thesis is that in our organizations the processes of knowledge sharing are of the non-institutionalized exchange forms which inhibit the flow of knowledge in an organization. Our position is that the sharing of knowledge should be raised from the level of non-institutionalized exchange to the level of institutional exchange, which would be more efficient, stable, regulated and thus sustained. We are confident that with the production of a coherent framework in which the interaction takes place on both levels (on the micro level, the level of the individual, and the macro level, the collective or organizational level) we can discover the mechanisms of exchange, transmissions and circulation of knowledge within an organization to a certain extent. The purpose of this paper is to develop a conceptual framework that will be able to integrate the micro and the macro level of the understanding of the transfer of knowledge within an organization and the integration of different theoretical per- 
spectives and different levels of analysis into a single coherent framework.

We understand that the social exchange theory does not explain the whole complexity of the processes of knowledge sharing within an organization. Its advantage lies in the fact that it can clarify the assumptions of the actions by individuals in an organization and approaches the problem of knowledge sharing from the pure empirical level into the more complex level of analysis.

\section{KNOWLEDGE SHARING AS THE KEY DIMENSION OF KNOWLEDGE MANAGEMENT}

Due to the belief that the creation and sharing of knowledge are essential for longterm organizational effectiveness there exists a growing interest for knowledge management itself. Knowledge management is defined as the process by which an organization creates, captures, acquires and applies knowledge in order to maintain and enhance its impact (Nonaka and Takeuchi, 1995). Various authors discuss the specific processes that are associated with knowledge management. Seng et al (2002) have developed five stages in the process of knowledge management: a) acquisition of knowledge is understood as recorded steps involved in solving a problem; b) the storage of knowledge is understood as the keeping of information contained in databases, storage, applications, or any other production system; c) knowledge processing, which includes sorting, filtering, organizing, analysing, comparing and searching for knowledge; d) sharing of knowledge, which includes the distribution of information through the system or personal interaction, simultaneously or sequentially; e) use of knowledge, which means solving problems with the purpose of achieving the objectives of the organization.

The management of knowledge is both an objective and a process. As an objective, claim Bollinger and Smith (2001), knowledge management is fully focused on the transfer of knowledge and information for the benefit of the organization (Novak, Roblek and Devetak, 2013). Therefore, the abovementioned fourth stage of the process, which is the transfer of knowledge, attracted the most attention of researches. Sveiby (2007) has defined nine levels of knowledge transfer within an organization.

The empirical evidence, which has been developed in the last decade in the field of knowledge management deals with knowledge sharing from different perspectives. The vast majority of research has dealt with the problem of obstacles (Dixon, 2000; Cabrera et al., 2006; Sveiby, 2007). The following strong interest has developed in the study of motivation of employees for the sharing of knowledge and the role of human resource management within an organization that promotes this type of sharing (Minbeava, 2005).

Minbaeva (2005) examined the factors which contribute to the possibility of receiving knowledge and also the environment that supports knowledge sharing. (1) The possibility of receiving knowledge includes both the individual's ability and motivation. (2) Factors affecting the adoption of knowledge are: a) prior knowledge of recipients and b) the intensity of dedicated effort. There is much evidence to suggest that investing in employee training increases human capital of an organization, which has a positive effect on later performance of the organization.

Researchers have determined that education and training have the biggest impact on the growth of human capital, which is directly linked to the quality of the workforce. Training and education of employees is critical for organizations to meet the needs for new and highly complex abilities and skills dictated by global competition, changes in technology and organizational structures. Bessant and Venables (2008) show that in the $21^{\text {st }}$ century, a turnaround has occurred in the economy, in which "wealth is created through knowledge". The OECD estimates that approximately one billion dollars is spent each year (in the public and private sector) to create new knowledge, which extends the boundaries and creates breakthroughs for technological advances.

Numerous studies have found a link between the different practices of education and training, and various measures of organizational performance (Becker and Huselid, 1998). All, of course, did not find a strong and positive relationship but it is generally considered that the latter does exist (Cunha et al., 2003; Nikandrou et al., 2008). Nikandrou et al. (2008) have demonstrated many factors that mediate the relationship between training, education and the performance of organizations such as cultural, institutional and organizational factors. But the intensification of global competition and the relative success of economies that give emphasis on investment in education have resulted in the recognition of the importance of education and training in recent years. Practitioners of human resource 
management report that education and training is one of the biggest challenges for them in the transition into the new millennium (Nikandrou et al., 2008).

Blacker (1995) argues that there are different types of organizations, depending on whether the knowledge in them is "embodied" (embodied), "imprinted" (embedded), "intellectualized" (en-brained) or "culturally integrated" (culturally integrated ). 1. Certain organizations depend on the experts and rely on "embodied" (embodied) knowledge of its key members. In these organizations the effectiveness of the experts is key; for example, organizations such as hospitals. Their basic problem is the nature and development of individual competences. 2. Other organizations that are based on routine knowledge are heavily dependent on tangible knowledge embedded in technologies, rules and procedures. These organizations are typically capital, technological and labour intensive. Machine bureaucracy is a typical example. The greatest problem they face is the development of integrated computer systems. 3. Organizations that depend on the employees, who analyse symbols, rely heavily on "intellectualized" (en-brained) knowledge and skills of key members. Business problem-solving and manipulation of symbols is a key skill in such organizations. An example of such an organization that is so intensely knowledge-based is a computer consultancy. 4. The communication-intensive organizations are heavily dependent on "culturally integrated" knowledge and common understanding. Creating knowledge in innovatively integrated production is a key problem of such organizations. Adhocracy is a classic example of this type of organization.

In doing so, it is very important to understand that regardless of the type of organization, individual progress in skills of the individual members of the organization is very important. Lam (2000) further developed a typology of organizational structures, especially in terms of knowledge sharing. Lam (2000) found that it is particularly important to pay attention to the type of knowledge that is being shared. Due to the different roles of their knowledge in an organization and the different levels of autonomy in the use of knowledge, employees have different views on when, why and to whom they provide certain knowledge. Precisely because of such views, Lam and Lambermont-Ford (2010) note that it is necessary to motivate employees differently, using various motivators in order to promote the sharing of knowledge and not to hoard it.
That the process of knowledge sharing within an organization is failing to achieve optimal results can be seen through the following arguments: Ruggless (1998) studied 431 American and European organizations and found significant barriers that prevent the sharing of knowledge. Riege (2005) and Sveiby (2007) have identified barriers inhibiting knowledge sharing. The context of knowledge sharing, in particular the culture and climate of an organization, was (referring to the context) studied by Al-Alawi et al. (2007). Organizational characteristics (such as size, age, structure and format) that affect the process of knowledge sharing have been studied at Rhodes al. (2008). Social ties and trust in the processes of knowledge sharing have been studied by Yang and Chen (2007) and Van Wijk et al. (2008).

Riege (2005) has identified 39 barriers in most works dealing with processes which impede (or obstruct) the sharing of knowledge. He divided them into organizational problems (such as the lack of a strategy for knowledge management, proper management, the lack of adequate space and time, inappropriate culture, lack of rewards and incentives, high competitiveness among employees); and problems that stem from individuals (low awareness of the value of knowledge, differences between individuals, lack of communication skills, retention of knowledge and the belief that knowledge is power, fear of job loss, lack of trust); and technological barriers (such as inefficient IT support).

Sveiby (2007) identified 91 problems that adversely affect the processes of knowledge sharing within an organization. Namely: the mentality of functional division within organizations (11.1\%); technological problems (7.8\%); disinterest of management for knowledge-sharing processes within an organization (7.6\%); a mentality that knowledge retention is defined as power of the individual in an organization $(6.0 \%)$; the absence of formal rules and procedures for knowledge sharing $(5.0 \%)$; lack of time $(4.5 \%)$; failure to realize the promises made by management $(3.7 \%)$; lack of support by the leaders $(3.0 \%)$ and the leaders are skeptical of change itself $(1.9 \%)$. 
(IJCRSEE) International Journal of Cognitive Research in Science, Engineering and Education Vol. 3, No.2, 2015.

Table 1. Factors and obstacles that have been studied in the field of knowledge sharing in the past fifteen years.

\begin{tabular}{|c|c|c|}
\hline $\begin{array}{c}\text { Factors at the organizational } \\
\text { level }\end{array}$ & $\begin{array}{c}\text { Factors at the individual } \\
\text { level }\end{array}$ & Factors of knowledge itself \\
\hline $\begin{array}{l}\text { Culture, climate, A1-Alawi } \\
\text { at al. (2007), } \\
\text { Chennamanenia, Teng and } \\
\text { Raja (2012), Ruggless } \\
\text { (1998), Hislop (2005), } \\
\text { Reyesa and Zapata (2014) }\end{array}$ & $\begin{array}{l}\text { Knowledge is power of the } \\
\text { individual (Hislop 2005) }\end{array}$ & $\begin{array}{l}\text { Explicit knowledge Nonaka } \\
\text { and Takeuchi (1995), Ma, } \\
\text { Huang, Wu, Dong, and Qi } \\
(2014) \text {. }\end{array}$ \\
\hline $\begin{array}{l}\text { Size, age, structure and } \\
\text { form of organization } \\
\text { Ruggless (1998), Rhodes at } \\
\text { al. (2008) }\end{array}$ & $\begin{array}{l}\text { Susceptibility to new } \\
\text { knowledge Darroch (2003) }\end{array}$ & $\begin{array}{l}\text { Implicit knowledge Nonaka } \\
\text { and Takeuchi (1995), Lam } \\
\text { and Lambermnot-Ford } \\
(2010) \mathrm{Ma} \text {, Huang, Wu, } \\
\text { Dong, and Qi (2014). }\end{array}$ \\
\hline $\begin{array}{l}\text { Social ties and trust Yang } \\
\text { and Chen (2007), van Wijk } \\
\text { et al. (2008) }\end{array}$ & $\begin{array}{l}\text { Motivation Sveiby (2007), } \\
\text { Cook, Cook 2005), Lam and } \\
\text { Lambermnot-Ford (2010), } \\
\text { Amayah (2013) }\end{array}$ & $\begin{array}{l}\text { Uncertainty, incarnation, } \\
\text { objectification, expression } \\
\text { Yanda and Chen (2007) }\end{array}$ \\
\hline $\begin{array}{l}\text { Communications } \\
\text { technology Ruggless } \\
\text { (1998), Sveiby (2007), } \\
\text { Ahmad and Daghfous } \\
\text { (2010) }\end{array}$ & $\begin{array}{l}\text { Views Bock and Kim (200), } \\
\text { Cabrera and Cabrera (2006), } \\
\text { attitudes Chennamanenia, } \\
\text { Teng and Raja (2012) }\end{array}$ & \\
\hline $\begin{array}{l}\text { Reward system Ruggless } \\
\text { (1998) }\end{array}$ & $\begin{array}{l}\text { Personality types Brazelton, } \\
\text { Gorry (2003), Cabrera et al. } \\
(2006)\end{array}$ & \\
\hline $\begin{array}{l}\text { Fluctuation Ruggless } \\
\text { (1998) }\end{array}$ & $\begin{array}{l}\text { Subjective norms } \\
\text { Chennamanenia, Teng and } \\
\text { Raja (2012) }\end{array}$ & \\
\hline $\begin{array}{l}\text { Bureaucratic obstacles } \\
\text { Sveiby (2007) }\end{array}$ & $\begin{array}{l}\text { Intentions Chennamanenia, } \\
\text { Teng and Raja (2012) }\end{array}$ & \\
\hline $\begin{array}{l}\text { Disinterest of management } \\
\text { Sveiby (2007) }\end{array}$ & $\begin{array}{l}\text { Perceived control of } \\
\text { behaviour Chennamanenia, } \\
\text { Teng and Raja (2012) }\end{array}$ & \\
\hline $\begin{array}{l}\text { Absence of formal rules and } \\
\text { procedures Sveiby (2007) }\end{array}$ & $\begin{array}{l}\text { Collectivism individualism } \\
\text { Huang, Davison \& Gu } \\
\text { (2011), Ma, Huang, Wu, } \\
\text { Dong, and Qi (2014). }\end{array}$ & \\
\hline $\begin{array}{l}\text { Lack of time Sveiby (2007), } \\
\text { Riege (2005) } \\
\text { Lack of support Sveiby } \\
(2007), \text { Riege (2005) }\end{array}$ & & \\
\hline $\begin{array}{l}\text { Organizational structure, } \\
\text { Lam (2000), Sharma, Singh } \\
\text { and Neha (2012) }\end{array}$ & & \\
\hline
\end{tabular}

Source: Mesner Andolšek, D., and Andolšek, S. (2011). Knowledge Sharing Through Social Exchange Theory Perspective. Organizacija, 44(4), 140-152.

If we analyse which factors are most strongly represented in literature about the process of imparting knowledge, we see that Table 1 shows that the primacy of attention and research on the factors of knowledge sharing within an organization acquired the macro level of treatment of this process - i.e. organizational level. The micro level, therefore, the level of the individual, has also been considered and analysed in the process of imparting knowledge in organizations. We can see that researchers have dealt with the motivation of individuals to share their knowledge. Views are a significant factor in the sharing of knowledge (Bock and Kim 2002). The perception of an individual, including the belief that others in the organization (staff and leaders) expect that employees will share their knowledge to others, may be an important factor in promoting the process of knowledge sharing within an organization.

Also very important is the perception of individuals that includes the expectation of reciprocity from others, so that others in the organization share their knowledge rather than hoard it. Some individuals are more prone to passing on knowledge than others (Cabrera et al. 2006).

Meta-analysis of antecedences of knowledge sharing (Witherspoon, Bergner, Cockrell and Stone 2013) showed that there are three groups of antecedences: personal, reward and culture.

In the discussion on the factors that 
promote the sharing of knowledge within an organization it is obvious that there exists a weak point, as there is no specific analysis on the interpretation between organizational and individual factors imparting knowledge in an organization. Some authors argue that this is a practice of human resource management that could place these factors in a consistent framework. In order to promote the flow of knowledge within an organization, many organizations decided to introduce the practice of human resource management to facilitate the sharing of knowledge. Darroch (2003) analysed the practices and behaviour of employees in knowledge management. She measured the acquisition, storage, dissemination and application of knowledge. Oltra (2005) found that the practice of human resource management has a positive impact on the success of knowledge management. He also noted that it is not so important to discover an ideal practice for knowledge management; instead, it is more important for practices to be aligned with one another and with the requirements of industry, business strategy and the characteristics of knowledge workers.

Looking at Table 1, we can see that the authors have mainly dealt with the macro (collective, organizational) factors of the process of knowledge sharing within an organization. Considerably less analysis has been made of the micro-level processes. Therefore, we shall focus our attention on the micro level of the process of knowledge sharing within an organization. It is not only that an insufficient number of studies have been carried out on the level of the individual, it is also the case that they have been performed in a very specific manner. The individual is treated as an actor during one part of a particular situation and is facing the factors within that situation. So the individual is a part of the reward system, part of the organizational structure, part of the organizational culture. The individual is a part of the situation and as such reacts to it in a certain way. Interpretation of these approaches is as follows: the more the person is rewarded for the sharing of knowledge, the more he or she is willing to share knowledge and more knowledge will be shared with colleagues in the organization. In these studies, however, the concept of the individual has not been addressed sufficiently. Our purpose in the present analysis is to ask ourselves what is the nature of the individual in the process of knowledge sharing within an organization? What are the rules, norms that form the background affect how a person behaves in these processes? Ma et al. (2014) claim that although the sharing of knowledge is also affected by national and organizational culture, in the end it depends on her/his personal decision.

Some authors such as ( Cabrera and Cabrera, 2005; Wilkesmann et al., 2009; Antal and Richebe, 2009) have begun to analyse various theories such as the theory of social capital, the theory of social dilemmas and the social exchange theory to explain the social dynamics of knowledge sharing from an individual's perspective. However, this is only the beginning, which has failed to bring about a comprehensive analytical attempt at explaining how an individual functions within an organization. Most of these contributions focused on the theoretical perspective that explains the views of the individual on the topic of knowledge sharing through the theory of rational action and the theory of social dilemmas. According to these theories the knowledge of the individual is initially seen as private goods, which the individual does not want to share with others, as knowledge has the tendency to spread within an organization, excluding the individual in the process. The individual can, however, reap the benefits of organizational knowledge. Cabrera and Cabrera (2005) warn that the possibility of benefiting without having to contribute anything may lead to opportunistic behaviour and the "free rider" effect. Besides the fact that contributing knowledge costs time and effort, other costs for an individual are also at risk; the individual contributing their knowledge may lose the opportunity for advancement. With that knowledge the individual is able to contribute to the progress of other individuals, thus losing the advantage in the competitive race with others in the organization. Lam and LambermontFord speak of "the fear of the loss of value of the individual to the organization" (Lam and Lambermont-Ford, 2010). On the other hand, Hislop (2005) points out that knowledge is the power of the individual and because an organization is a hierarchical system, the sharing of knowledge within an organization is always difficult to trigger.

The theory of social exchange is useful as it can analyse the processes of knowledge sharing within an organization and allows insight into:

- the reasons why people share their knowledge,

- how to share knowledge with others,

- time spent sharing knowledge and

- what organizations can do to accelerate the process of knowledge sharing. 
In the following we will analyse the initial theoretical assumptions and explain the difference between economic and social exchange, thus defining the different understandings of the individual in the processes of exchange, represented by two disciplines, on the one hand with economics and on the other with sociology. The differences are critical, as it is only by detecting these differences in the perception of the individual and her/his activity that we can present a way it can be used to accelerate sharing of knowledge within an organization. This is also the main contribution of our paper.

\section{ECONOMIC AND SOCIAL EXCHANGE}

Blau (1964) defined the main difference between social and economic exchange. In economic exchange private ownership and a large number of objects exist which are available on the open market and can be obtained by anyone who can buy goods at the price determined by supply and demand. Customers can negotiate prices. The payment for goods is legally ensured, payment is determined by amount, time and space. The main difference between economic and social exchange is the existence of "nonspecific obligations". Social exchange includes the exchange of services among actors which forms "diffuse future obligations", which are not precisely defined, as they are in an economic exchange. Payback is not defined by amount, time and space.

The second difference is that in social exchange "the payback is not a matter of negotiation, but is at the discretion of a giver" (Blau, 1964). In general, social exchange is more specific, as it takes place among a smaller number of actors compared to economic exchange.

Social exchange occurs in an organizational context, which is by and large a highly competitive environment. Although employees as individuals, groups, teams or departments are competing over resources, they have to cooperate in order to attain common goals. In such a situation, knowledge sharing is a part of the exchange process and knowledge is a very important source of exchange. The sharing of knowledge in an organization has its exchange background although precise calculation and selections are not emphasized.

In general, Figure 1 shows that social exchange takes place under specific conditions over which members want to hold control.
People enter relations in order to acquire resources that belong to (controlled by) others. In the process of social exchange employees exchange different resources: material resources and symbolic resources, such as information, knowledge, power, respect, belongings, sanctions, honour, emotions, etc. (Etzioni, 1975). The process of social exchange is illustrated in the following scheme. 1964)

Figure 1. Economic and social exchange (Blau,

\begin{tabular}{|l|}
\hline Economic exchange: \\
- Private ownership \\
- Large number of objects \\
- Free exchange \\
- Prices are negotiated \\
- Payment consists of the defined \\
amount, time and space \\
\hline
\end{tabular}

Social exchange:
- Diffuse future obligations
- Small number of actors
- More specific
- Payback is not negotiated, but is at the
discretion of a giver
- Payback is not amount, time and space
defined
- Source of exchange: material or
symbolic (info, love, power,
knowledge, emotion, respect, honour)

There are many types of exchange in an organization. Homans (1961), for example, specified two forms of behaviour in the social exchange process: sub-institutionalised and institutionalised. The first is more elementary and the second is more complex.

Figure 2. The process of social exchange

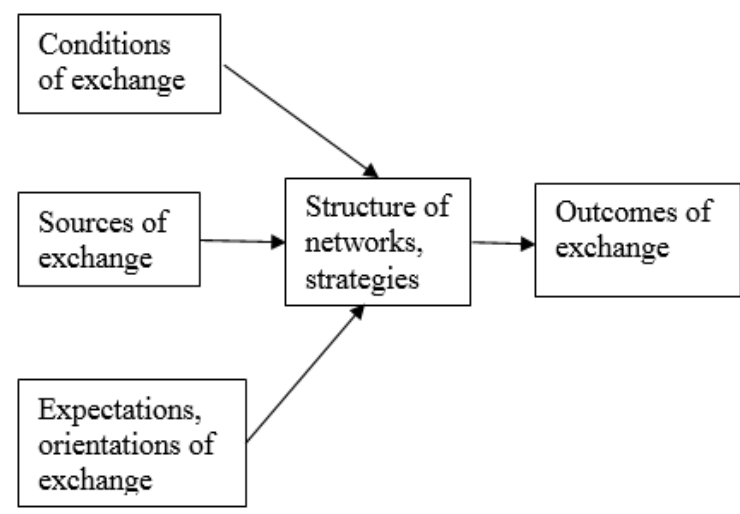

In the second, exchange as an institutionalized process, exchange is regulated with rules, values and norms, while in the first the exchange is more an unregulated process where actors seek favourable outcomes only in direct exchange. Homans (1961) defined sub-institutional behaviour as when actors are acting directly upon the actions of others regardless of the rules, which may or may not exist in a situation. Homans (1961) said it is important to know "how employees will help each other even when formal rules do not demand their mutual cooperation". Knowledge sharing in an organization occurs in the form of sub-institutionalized behavior. 
Figure 3. Knowledge sharing as a sub-institutional process (Homans, 1961)

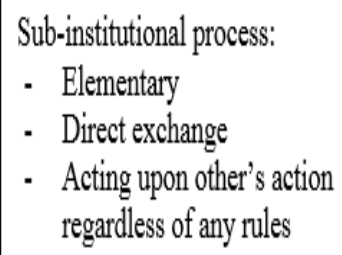

- Direct exchange

- Acting upon other's action regardless of any rules



\subsection{Knowledge sharing in organiza- tions as a sub-institutional process}

Up until now, knowledge sharing in organizations was seen as a sub-institutional process, which occurs in an institutional emptiness. Spontaneous transactions among actors in the exchange process are not subjected to any institutional pressure and exchange happens in a "pure form" (mutual help, problemsolving or mutual attraction among employees). To understand this process we will look at the process of social exchange in greater detail.

In an organization, with its hierarchical structure, a tendency to withhold information exists. But on the other hand, an organization is not just a sum of individuals who want to keep important information to themselves. In an organization, a lot of work constellations, groups and teams exist, forming a second tendency to inform and to keep other members of the group in the loop. Shared meanings for preserving common themes, shared definitions of reality, synchronisation of values and goals, all these processes demand information sharing.

A micro interactional space among organizational members and groups exists where information and knowledge are a source of exchange. There is a lot of information in free exchange. Small efforts and a few costs are demanded to acquire this information. But certain information, which demands greater effort and higher costs to obtain, is under strict control of its holder. Important, high-value sources exist, which are under protection of their bearer. This is self-protection behaviour of an individual. The actor retains inner domains for his autonomous use (Goffman, 2009). The borders of protected domains are under the supervision of their owner, since they are important for keeping good exchange conditions in the future. Actors exert constant efforts to maintain reciprocity and stable conditions during the exchange.
Employees of an organization do not share knowledge because they do not want to accept an inferior exchange standard. Successfulness in exchange is connected with favourable exchange outcomes.

In order to establish such circumstances, the organization has to design a HRM policy that will ensure better reward outcomes for employees. If employees understand that they can enter in a valuable exchange process, they will do so.

Homans (1961) revealed one of the basic secrets of human exchange. Namely, actors are prepared to enter into an exchange process under the following terms:

1. Everyone has to have something that others do not have, but she/he needs;

2. They change approximately the same values;

3. Everybody has to get more than she/ he gives, otherwise the exchange would be meaningless and would not occur.

Thibaut and Kelley (1959) argued that actors in an exchange process will orient themselves on the basis of an expected ratio between costs and rewards. They designed a matrix of behavioural chain for the dyadic situation ( $\mathrm{A}$ and $\mathrm{B}$ actor).

Figure 4. Thibaut and Kelley (1959) matrix of expected rewards and costs:

\section{A behavioural repertoire}

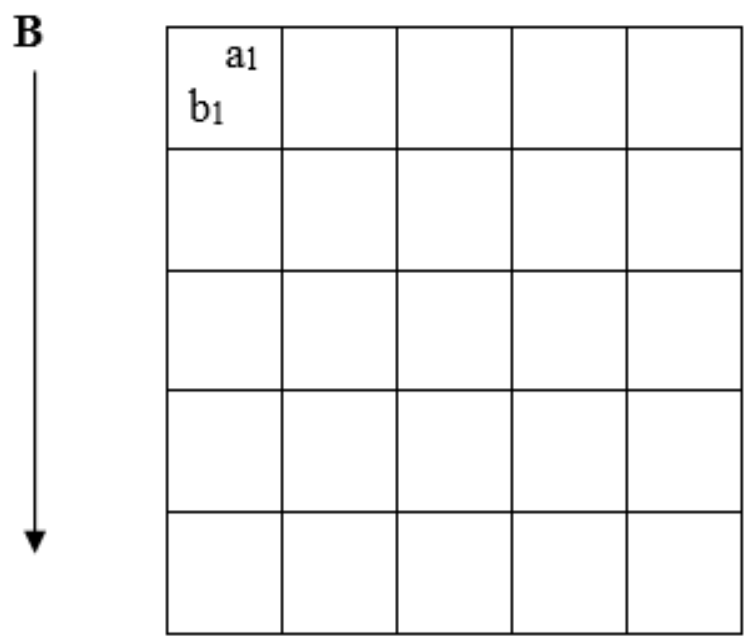


Figure 5. Each cell of a matrix has a specific relation between rewards and costs for actor A and B:

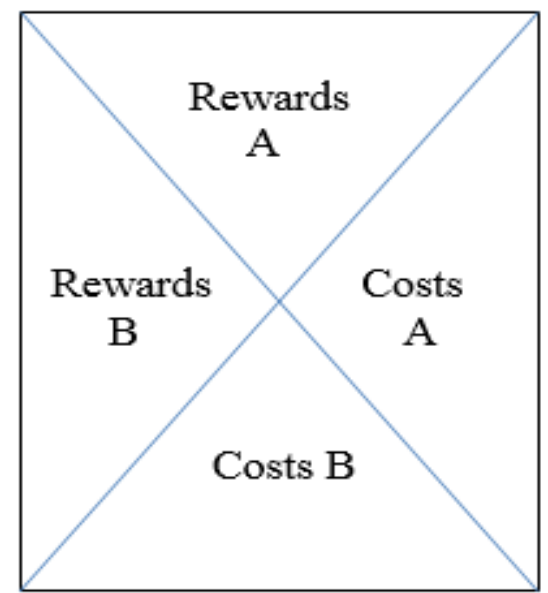

The behavioural chain of both actors (A and $\mathrm{B}$ ) is selective and changeable, depending on expected rewards and costs. Many outcomes are possible. The matrix shows how outcomes can change with regard to different behavioural patterns of each actor. For example, information given to the other can be connected with smaller or bigger costs in time or effort, but it is also connected with high respect, honour and commitment of the information receiver. For example, if the costs for actor A are 4 and rewards are 6, than the total positive outcome for actor $\mathrm{A}$ is 2 . On the other side, if for actor $\mathrm{B}$ the information given is very valuable and he strongly depends on it, the reward for him is 6 , but he is not highly subordinate to actor $\mathrm{A}$, so the costs for actor $B$ is just 1 , then the total positive outcome for $\mathrm{B}$ is 5 . This situation can be inserted into the matrix; cell number 1 is $a_{1} b_{1}$ as follows.

Figure 6. Matrix of rewards

Cell no. 1 of the matrix

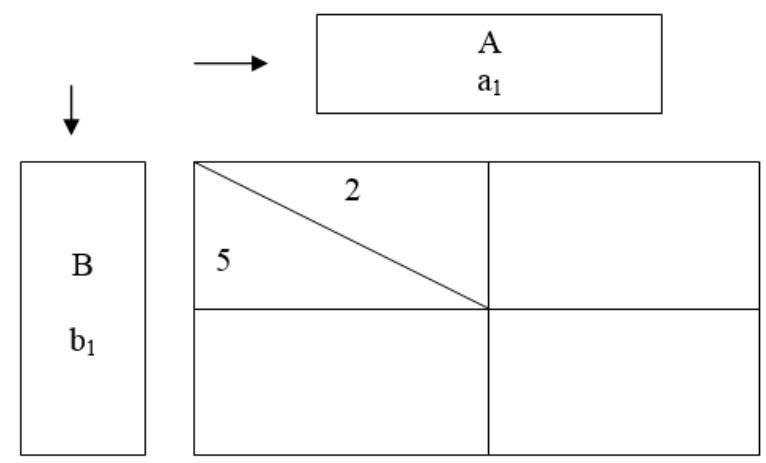

Actor A has in his behavioural repertoire at least two options: to offer information or not, which for her/him means different total outcomes (rewards minus costs); and B can accept or refuse the information as well, depending on her/his calculation.
Thibaut and Kelley (1959) argued that an actor values the outcomes on the basis of two standards which do not fall under economic criteria. The first standard represents the level of attraction within the relationship: for the person the involvement in the interaction could prove more or less satisfactory. They named the standard as "comparison level" CL. The second standard sets the bottom level for the outcomes in the light of an alternative. It is the level where a person makes the decision to either continue or stop the interaction. They named the standard as "comparison level for alternatives" $\mathrm{CL}_{\text {alt }}$. So for a person, one relation might not be very satisfactory (below the $\mathrm{CL}$ ), yet he will not discontinue the interaction. This will occur when the level of dissatisfaction reaches the lowest level in the light of alternatives which are at his disposal (below $\left(L_{21}\right)$. As soon as the outcome drops below the $\mathrm{CL}_{\text {alt }}$ the person will break the interaction. For two people, the condition to continue the interaction is that both of them retain the relation between rewards and costs beyond $\mathrm{CL}_{\text {alt }}$.

Thibaut and Kelley (1959) argued that valuation of outcomes is connected with his $\mathrm{CL}$, which is a reflection of all his prior outcomes. For a person, an appropriate level of outcomes is expected on the basis of all known past outcomes. Satisfaction with the wage is not only connected to a comparison of all past wages of an employee, but rather to the professional role, education and her/his tenure. An employee is part of hieratical structure of an organization as well and she/he tends to compares her/himself with others in a company or organization. She/he also compares her/ his wage to wages of colleagues, trade union arrangements and so on.

To share knowledge means that all costs and rewards are taken into consideration. But first, conditions to enter the exchange with others have to exist. According to Homans (1961):

1. She/he will not enter the exchange without the existence of a need to do so,

2. If she/he shares, she/he has to receive something valuable for her/ him in return,

3. It has to be a favourable exchange with rewarded outcomes.

According to Thibaut and Kelley (1959) she/he will evaluate the outcome by comparing CL and $\mathrm{CL}_{\text {alt }}$. Only then will she/he decide to either continue with the exchange process in the future or drop out of it. 


\section{KNOWLEDGE SHARING IN ORGANIZATIONS AS AN INSTITUTIONAL PROCESS}

It is important to mention that besides the dyadic and triadic exchange processes in an organization, indirect exchanges also exist. This form of exchange is an exchange between individuals, groups and organizations, based on values, norms and regulated social relations. Within these relationships, individuals either calculate their costs and rewards or they act spontaneously and retain their presence as long as these relationships have favourable outcomes for them.

"Elementary social behaviour" (Homans, 1961), which means direct social exchange, does not exist separate from institutional exchange processes. The spheres of human behaviour and actions, which are more regulated and institutionally arranged, are not isolated from the rules of exchange. "Normed and institutionalised" does not mean something else, isolated from the exchange process. It is not an alternative to free exchange. Relations on a macro level: (1) between individuals and organizations; (2) among organizations, and (3) between organization and society are still exchange processes, but the exchange is indirect and regulated by rules, which ensure appropriate relations, social control and stabile transactions. However, in these relations, new media occur: money, values and norms. On this level, transactions are based not only on mutual trust, attraction and mutual rewards, but people also act as representatives of their roles determined by normative rules and organizational goals, strategies, rewards paid by an organization, and not merely from the direct exchange process. Exchange processes on this level are more complicated, are given new dimensions and qualities, and are not excluded. Norms and values are the media in social exchange processes as money is in economic transactions. Norms and values stabilize behaviour and determine it in advance. Norms also ensure justice in the exchange process.

A number of authors have concluded that a knowledge sharing supportive organizational culture must be present in organizations for knowledge management activities to succeed (DiTienne at al., 2004). Transgression from micro to macro conditions in the exchange process includes the growing importance of shared values, which also have a mediating role in the process of indirect social exchange. Without knowledge sharing supportive organizational culture values cannot play a mediat- ing role in indirect exchange processes.

Direct and indirect exchange processes have to be understood as mutually intertwined, where individuals act as role holders, bear rules in mind, are in direct or indirect relations, and can calculate their short or long-term advantages. This can be done only because the institutionalization of social life (norms and values) enables a long-term duration of interactive structures among individuals, groups and organizations.

To ensure knowledge sharing processes as a durable and long-lasting orientation of employees, organizations must develop knowledge sharing policies, supported by value orientations, rules and norms. These are specific value standards, which control orientations and interaction among people.

To ensure knowledge sharing and transfer as a durable and lasting process in organizations it is important to solve the problems of:

- how to retain stability of the exchange process with less costs,

- how to retain the stability of the comparison level (CL and $\mathrm{CL}_{\text {alt }}$ ) of individuals involved in exchange processes,

- its predictability, and

- how to establish consistent coordination based on indirect exchange processes.

Retention of the established order of exchange processes demands its institutionalization. Institutionalization is the first condition of durable exchange processes. Interaction process (knowledge sharing) in an organization should not just be a result of the contingent direct mutual exchange amongst individuals, but rather should become a part of the existing structure of values and norms, which last as a complex of established conditions of actions and mutual transactions. Institutionalized patterns of interaction present the individual with various rewards.

Blau (1964) for example made the classification of rewards obtained in an exchange process which are divided into two groups, spontaneous and calculated. Spontaneous action rewards could be subdivided into intrinsic (attraction) and extrinsic (social acceptability, respect, status), while calculated action rewards could either also be intrinsic (social approval) or extrinsic (material rewards, subordination, support, power). If rewards are lower than expected or there is none at all, individuals will not enter the exchange process or will seek different institutional arrange- 
ments. Rewards management for knowledge sharing in an organization has to be seen as holistic, which means that reward strategies are connected to the overall HRM climate in an organization vis-à-vis market expectations for each occupational category. It is obvious why financial rewards alone do not promote knowledge sharing in organizations (Dixon, 2002).

Institutionalized patterns of interaction do not just limit the behaviour of individuals but also frame exchange processes. This includes the $\mathrm{CL}$ and $\mathrm{CL}_{\text {alt }}$ of outcomes among individuals, groups and organizations as well. It means that $\mathrm{CL}$ and $\mathrm{CL}_{\text {alt }}$ are not just results of direct and indirect transactional processes based on mutual attraction and competition for scarce resources among individuals, but are also determined by institutional processes as well. Individuals on the other hand enter exchange processes based on individual calculations of rewards and costs and continue these exchanges as long as rewards are estimated as appropriate and just.

Figure 7. Knowledge sharing in organizations as an institutional process

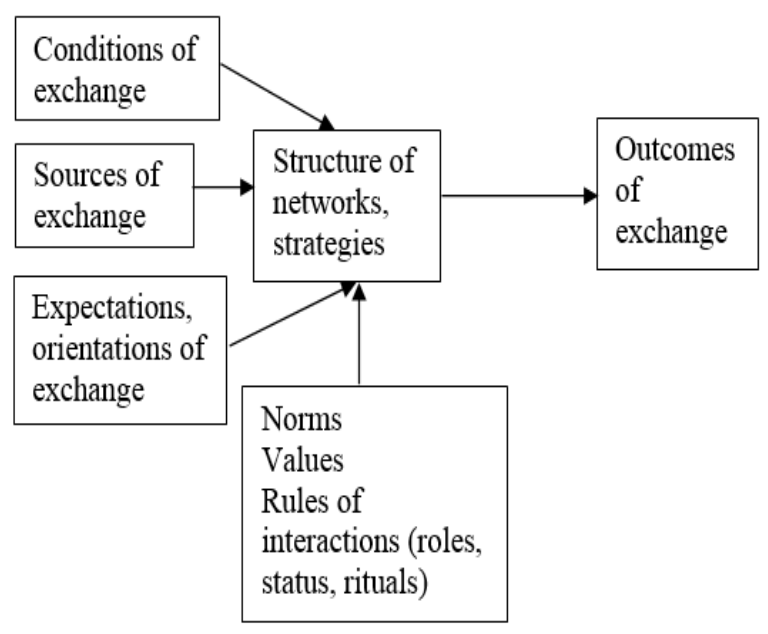

Table 2. The role of Human Resource Management in the knowledge sharing process

\begin{tabular}{lll}
\hline $\begin{array}{l}\text { Established } \\
\text { conditions for } \\
\text { interactions }\end{array}$ & $\begin{array}{l}\text { Structures, } \\
\text { processes, } \\
\text { technology }\end{array}$ & $\begin{array}{l}\text { Teams, communities of } \\
\text { practices, } \\
\text { ICT for communication }\end{array}$ \\
\hline Coordination & $\begin{array}{l}\text { Person, } \\
\text { role, body }\end{array}$ & KMO, HRM \\
\hline $\begin{array}{l}\text { Outcomes } \\
\text { CL, CL alt }\end{array}$ & $\begin{array}{l}\text { Intrinsic, } \\
\text { extrinsic rewards }\end{array}$ & $\begin{array}{l}\text { Incentive scheme, } \\
\text { motivation }\end{array}$ \\
\hline Predictability & $\begin{array}{l}\text { Forming routines } \\
\text { communication, briefing }\end{array}$ & $\begin{array}{l}\text { Meetings, two-way } \\
\text { commen }\end{array}$ \\
\hline Norms & $\begin{array}{l}\text { Rules when it is } \\
\text { obligatory to } \\
\text { exchange practices, } \\
\text { experiences, views, } \\
\text { information }\end{array}$ & $\begin{array}{l}\text { Forms of exchange, } \\
\text { Time oxchange }\end{array}$ \\
\hline Duration & Institutionalisation & $\begin{array}{l}\text { Mentors, socialization, } \\
\text { culture, management }\end{array}$ \\
\hline Values & $\begin{array}{l}\text { Articulation of } \\
\text { values, role models, } \\
\text { heroes }\end{array}$ & $\begin{array}{l}\text { Code of ethics, } \\
\text { statements, managers }\end{array}$ \\
\hline
\end{tabular}

Human Resource Management can promote the knowledge sharing process by developing a knowledge sharing culture with designing structure, processes, rules and routines which are directed toward knowledge sharing activities. In addition, Human Resource Management can initiate a process of development values and norms which support knowledge sharing among employees.

\section{CONCLUSIONS}

Knowledge sharing among members of an organization, as well as between an organization and its customers, suppliers and alliance partners, greatly facilitates the process of improving the quality of customer service, reducing production cycles, increasing the cooperation between different departmental units and consolidating the relationships with alliance partners, which thus enhances an organization's efficiency and functionality.

The focus of this study was to identify key factors that affect knowledge sharing among members of an organization. We conceptualized knowledge sharing among organizational members as a social exchange process.

The analysis of a macro structure demands the inclusiveness of more than just one level of a social organization. To analyse the macro structure one has to be aware of its substructures such as groups and individuals. Individual actors, who enter into an 
indirect social exchange process, have their own motives, needs and preferences besides their common goals and interests. In the case of exchange between groups, this exchange is indirect, but a lot of direct exchange processes take place within it.

A more complex process of knowledge sharing would appear if it were to be understood as an institutionalised activity, regulated by norms, values or other rules. In this respect, Human Resource interventions are the first important step toward the promotion of knowledge sharing in an organization.

\section{ACKNOWLEDGEMENTS}

The authors would like to acknowledge the two anonymous reviewers for their reviews.

We would also like to acknowledge the invaluable advice provided by Dana Minbaeva, for the earliest version of the paper.

Our thanks go to the two editors of the journals for indispensable support received in the final stage of the publication.

\section{Conflict of interests}

Authors declare no conflict of interest.

\section{REFERENCES}

Al-Alawi, I. A., Yousif Al-Marzooqi, N., \& Fraidoon Mohammed, Y. (2007). Organizational culture and knowledge sharing: critical success factors. Journal of Knowledge Management, 11(2), 22-42.

Ahmad, N., \& Daghfous, A. (2010). Knowledge sharing through inter-organizational knowledge networks: Challenges and opportunities in the United Arab Emirates. European Business Review, 22(2), 153-174.

Amabile, T. (1997). Motivating creativity in organizations. California Management Review, 40(1), $39-58$.

Amayah, T.A. (2013). Determinants of knowledge sharing in a public sector organization. Journal of Knowledge Management, 17(3), 454-471.

Antal, A. B., \& Richebé, N. (2009). A passion for giving, a passion for sharing understanding knowledge sharing as gift exchange in academia. Journal of Management Inquiry, 18(1), 78-95.

Becker, B. E., \& Huselid, M. A. (1998). High performance work systems and firm performance: A synthesis of research and managerial implications. In Research in personnel and human resource management.

Bessant, J. R., \& Venables, T. (Eds.). (2008). Creating wealth from knowledge: meeting the innovation challenge. Edward Elgar Publishing.
Blackler, F. (1995). Knowledge, knowledge work and organizations: An overview and interpretation. Organization Studies, 16(6), 1021-1046.

Blankenship, S. S., \& Ruona, W. (2009). Exploring knowledge sharing in social structures: Potential contributions to an overall knowledge management strategy. Advances in Developing Human Resources, 11(3), 290-306.

Blau, P. M. (1964). Exchange and power in social life. Transaction Publishers.

Bock, G. W., \& Kim, Y. G. (2001). Breaking the myths of rewards: An exploratory study of attitudes about knowledge sharing. Pacis 2001 proceedings, 78.

Bollinger, A. S., \& Smith, R. D. (2001). Managing organizational knowledge as a strategic asset. Journal of Knowledge Management, 5(1), 8-18.

Cabrera, A., Collins, W. C., \& Salgado, J. F. (2006). Determinants of individual engagement in knowledge sharing. The International Journal of Human Resource Management, 17(2), 245-264.

Cabrera, E. F., \& Cabrera, A. (2005). Fostering knowledge sharing through people management practices. The International Journal of Human Resource Management, 16(5), 720-735.

Chennamaneni, A., Teng, J. T., \& Raja, M. K. (2012). A unified model of knowledge sharing behaviours: theoretical development and empirical test. Behaviour \& Information Technology, 31(11), 1097-1115.

Cook, L., \& Cook, J. (2004). Promoting organizational knowledge sharing. Innovations of knowledge management. Eds.Montano, B. IRM Press, Hershey.

Cunha, M., Morgado, A., \& Brewster, C. (2003). Market forces, strategic management, HRM practices and organizational performance, A model based in a European sample. Management Research, 1(1), 79-91.

Darroch, J. (2003). Developing a measure of knowledge management behaviors and practices. Journal of knowledge management, 7(5), 41-54.

DeTienne, K. B., Dyer, G., Hoopes, C., \& Harris, S. (2004). Toward a model of effective knowledge management and directions for future research: Culture, leadership, and CKOs. Journal of Leadership \& Organizational Studies, 10(4), 26-43.

Dixon, N. M. (2000). Common knowledge: How companies thrive by sharing what they know. Harvard Business Press.

Etzioni, A. (1975). Comparative Analysis of Complex Organizations, Revised and Enlarged Edition. The Free Press, New York.

Goffman, E. (2009). Relations in public. Transaction Publishers.

Hislop, D. (2003). Linking human resource management and knowledge management via commitment: A review and research agenda. Employee Relations, 25(2), 182-202.

Homans, G. C. (1961). Social behavior: Its elementary forms. Hacourt, Brace \& World Inc.

Huang, Q., Davison, R. M., \& Gu, J. (2011). The impact of trust, guanxi orientation and face on the intention of Chinese employees and managers to engage in peer-to-peer tacit and explicit knowledge sharing. Information Systems Journal, 21(6), 557-577.

Lam, A. (2000). Tacit knowledge, organizational learning and societal institutions: an integrated framework. Organization studies, 21(3), 487-513. 
(IJCRSEE) International Journal of Cognitive Research in Science, Engineering and Education

Vol. 3, No.2, 2015.

Lam, A., \& Lambermont-Ford, J. P. (2010). Knowledge sharing in organisational contexts: a motivationbased perspective. Journal of Knowledge Management, 14(1), 51-66.

Ma, Z., Huang, Y., Wu, J., Dong, W., \& Qi, L. (2014). What matters for knowledge sharing in collectivistic cultures? Empirical evidence from China.Journal of Knowledge Management, 18(5), 1004-1019.

Martín Cruz, N., Martín Pérez, V., \& Trevilla Cantero, C. (2009). The influence of employee motivation on knowledge transfer. Journal of Knowledge Management, 13(6), 478-490.

Mesner Andolšek, D., \& Andolšek, S. (2011). Knowledge Sharing Through Social Exchange Theory Perspective. Organizacija, 44(4), 140-152.

Michailova, S., \& Husted, K. (2003). Knowledge-sharing hostility in Russian firms. California management review, 45(3), 59-77.

Minbaeva, D. B. (2005). HRM practices and MNC knowledge transfer. Personnel Review, 34(1), 125-144.

Nikandrou, I., Apospori, E., Panayotopoulou, L., Stavrou, E. T., \& Papalexandris, N. (2008). Training and firm performance in Europe: the impact of national and organizational characteristics. The International Journal of Human Resource Management, 19(11), 2057-2078.

Nonaka, I., \& Takeuchi, H. (1995). The knowledgecreating company: How Japanese companies create the dynamics of innovation. Oxford university press.

Novak, R., Roblek, V., \& Devetak, G. (2013). Relation between Knowledge Management and Turnover in Slovenian Micro and Small Start-Up Organisations. Organizacija, 46(3), 99-107.

Oltra, V. (2005). Knowledge management effectiveness factors: the role of HRM. Journal of Knowledge Management, 9(4), 70-86.

Reyes Villamizar M. M., \& Castañeda Zapata, D. I. (2014). Relation Between Organizational Climate and its Dimensions and Knowledge-sharing Behavior among Knowledge Workers. In ternational Journal of Psychological Research, $7(2), 64-75$

Rhodes, J., Hung, R., Lok, P., Ya-Hui Lien, B., \& Wu, C. M. (2008). Factors influencing organizational knowledge transfer: implication for corporate performance. Journal of knowledge management, 12(3), 84-100.

Riege, A. (2005). Three-dozen knowledge-sharing barriers managers must consider. Journal of knowledge management, 9(3), 18-35.

Ruggles, R. (1998). The state of the notion. California management review, 40(3), 80-89.

Seng Veng, C., Zannes, E., \& Wayne Pace, R. (2002). The contributions of knowledge management to workplace learning. Journal of Workplace Learning, 14(4), 138-147.

Sharma, B. P., \& Singh, M. D. (2012). Knowledge sharing barriers: An approach of interpretive structural modeling. IUP Journal of Knowledge Management, 10(3), 35.

Sharratt, M., \& Usoro, A. (2003). Understanding knowledge-sharing in online communities of practice. Electronic Journal on Knowledge Management, 1(2), 187-196.

Sveiby, E.K. (2007). Disabling the context for knowledge work: the role of managers' behaviours Management Decision, 45(10), 1636-1655.
Thibaut, J. W., \& Kelley, H. H. (1959). The social psychology of groups, Wiley \& Sons Inc., New York.

Van Wijk, R., Jansen, J. J., \& Lyles, M. A. (2008). Inter-and intra-organizational knowledge transfer: a meta-analytic review and assessment of its antecedents and consequences. Journal of Management Studies, 45(4), 830-853.

Wilkesmann, U., Wilkesmann, M., \& Virgillito, A. (2009). The absence of cooperation is not necessarily defection: Structural and motivational constraints of knowledge transfer in a social dilemma situation. Organization Studies,30(10), 1141-1164.

Witherspoon, C. L., Bergner, J., Cockrell, C., \& Stone, D. N. (2013). Antecedents of organizational knowledge sharing: a meta-analysis and critique. Journal of Knowledge Management, $17(2), 250-277$.

Yang, C., \& Chen, L. C. (2007). Can organizational knowledge capabilities affect knowledge sharing behavior?. Journal of Information Science, 33(1), 95-109. 